\title{
The Meaning of Recreation: Humanism in Society ${ }^{1}$ Northrop Frye
}

I BEGIN WITH the fact that my critical interests have always revolved around the Bible, not for doctrinal reasons but for reasons that had directly to do with my work as a literary critic. When I was still a junior instructor, I was trying to write a book on Blake and trying to teach Milton to undergraduates, and I complained to my departmental chairman that I was having some difficulty in reaching my students because we could no longer take for granted the working knowledge of the Bible that we used to be able to take. And a student without that knowledge simply does not know what is going on in English literature. My chairman said the only thing to do is to draft a course in the English Bible and teach it. He said, "How do you expect to teach Milton to students who don't know a Philistine from a Pharisee?" I said, "Perhaps in the kind of society they are going into, that particular distinction won't be important to them. "But I didn't often talk like that to my chairman, except in moments of stress, so I drafted the course and I'm still teaching it.

Recently I've become more and more preoccupied with what becomes of the Bibie when it is examined from the point of view of literary criticism. I think the first question that confronts one, then, is in what language has the Bible been written? The factual answers are Hebrew and Greek, but they hardly do justice to a book which has exerted most of its cultural influence in Latin and vernacular translations. Hebrew and Greek are, to use a useful French distinction, only the langue of the Bible; the langage is something else again. The question then arises, is there such a thing as a history of langage, and does the Bible have an historical context in that respect which one has to take account of?

That question took me to the eighteenth century Italian philosopher Vico, who was the first person to think seriously about such matters. Vico had worked on a theory of history according to which society goes through three different stages: a poetic age of the gods (a mythical age), an aristocratic age of the heroes, and a democratic age of the people. In his day there had been no permanently successful example of a democracy, so Vico assumed that after going through those three phases, society went into a ricorso, and did the whole thing all over again. He said too that there was a language for each of these stages: for the age of the gods there was a hieroglyphic language; for an age of the heroes, a hieratic language; and for an age of the people, a demotic language. These languages were all forms of writing because Vico believed that people communicated by signs before they could talk. His theory is bound up with a rather curious mythology according to which the original inhabitants of the world before the flood were giants who carried on in a very unseemly manner until they were terrified by a thunderstorm, after which they dashed into caves dragging their women behind them. So began private property. Vico was a favorite author of Joyce largely because Joyce was also terrified by thunderstorms.

1 Transcribed from a lecture given at The University of Iowa on April 12, 1979 and printed with Professor Frye's permission. 
It seemed to me that Vico's distinction was something that one could adapt, although it would have to be a very free adaptation. I won't buy his ricorso, at least not in the form in which he gives it. I don't think that people communicated by signs before they could talk. At the same time I do feel that this conception of three phases of language which have some kind of relationship to hieroglyphic, hieratic, and demotic might make a certain sense. I'd like to try out the idea on you.

I am not at the moment speaking of literature; I'll come to literature later. And I'm not speaking of the use of ordinary language, which I take it has been much the same from the Egyptian Old Kingdom to our own day. I'm speaking of the language of cultural ascendancy, the kind that survives in religious and literary documents. It seems to me that the language of Homer, of early Greek literature, and the language in which the bulk of the Old Testament is rooted belong to a phase of language which has something in common with what Vico meant by hieroglyphic. Language in this phase is conceived as something which emanates from the speaker towards the natural world and expresses a kind of identification with that world. In other words, it is fundamentally a metaphorical language, metaphor being, in this phase, not an ornament of language, but the way of thinking about language. It is hieroglyphic not in the sense of sign writing but of sign thinking, or rather of sign langage; the word evokes the image.

In a monumental study of Homer's vocabulary, a book called The Origins of European Thought by Onians, we are shown how intensely concrete Homer's vocabulary is. Words like "life" and "mind" and "soul" and "thought" and "passion," to say nothing of such terms as "time" and "space," have no genuine abstract reference at all. They are all concrete conceptions related to the action of the heart and the lungs and the brain. To be alive is to take breath into the lungs, and vitality consists of the sperm dripping down from the brain into the genital organs, or however Homer conceived it. Nor were these conceptions metaphors to Homer, though they are metaphors to us. We can only think of this kind of language as dominated by the metaphorical identification of subject and object. The core of the metaphor is this is that, $a$ is $b$; and the two things that are fundamental in the metaphor, the $a$ and the $b$, are something in the subject-something in personality-and something in the object-something in the natural world. Consequently the central conception in this phase of language is the conception of the god with the small $g$ because a god is essentially a metaphorical idea. You have sun gods and war gods and tree gods and so on in whom some aspect of personality is identified with some element in nature.

In this phase of language there is a powerfully magical residue. In Babylon on New Year's Day, the epic of creation, a poem called Enuma elish, was recited; and the reciting of the poem of creation on New Year's Day obviously helped to sustain and encourage the operations of nature in bringing the year around once again. Similarly warriors would begin their battles with boasts because boasting is a way of acquiring the words of power that may make them stronger than their opponents. Gods take an extremely dim view of human boasting for the same reason. If man acquires the word of power, 
he may unseat them from their position. And there are various themes in folktales such as the rash vow of Jepthah, who says, "I have given my word to the Lord and I cannot go back," expressing the feeling that the spoken word has already set up some kind of operation in the natural world.

In this phase of language, prose is intensely discontinuous. Prose consists of the kind of prose that you find in the Old Testament, broken down into kernels of law or commandment in the first five books, of oracle in the prophecies, of aphorism or proverb in the wisdom literature, of pericope in the Gospels. These sentences are surrounded by silence. You are not expected to argue with them; you are expected to brood over them and think about them. Similarly with Greek philosophy before Socrates; the pre-Socratic philosophers so called were really gurus, or spiritual leaders. They would utter various aphorisms like "you never step twice into the same river," or "all things flow," or "Don't eat beans," or something of that kind. When they were said by a Heraclitus or a Pythagoras, again you didn't argue because this was ipse dixit; this was what the master had said. You brooded and thought about it. Elsewhere in the world you find it as well. There are many books on yoga in India written in continuous prose but they all refer you to the yoga sutras of Patanjali, which are written in tight, gnarled epigrammatic aphorisms, each one of which could be a source of commentary in itself. And there are large vacant spaces between each aphorism.

This is the phase of language that seems to me to have been superseded in Greek culture by Plato, who began a second phase that dominated language down to the time of at least Kant and Hegel. In this second phase there is a stronger sense of individuality, words now being thought of primarily as the expression of thoughts, and to some degree as the residue of thoughts. The scholar Eric Havelock, who was a former colleague of mine, has written a book on Plato in which he associates the Platonic revolution in language with the development of writing. I don't question his scholarship, but I prefer to associate it with the development of continuous prose. That seems to me to have begun when Socrates approached the youth of Athens and said to them, "I don't know anything, unlike my predecessors, but I'm looking for something; come help me look." Those who responded found that they were moving along a linear trail of words, the trail that is known as dialectic. Dialectic is incorporated into Plato; in Aristotle it becomes the pattern of deductive and syllogistic reasoning. It's a ranging of verbal associations in a linear sequence so that they go marching like the Macedonian phalanx across reality. It's a sequential ordering of words in which the fact of sequential ordering becomes itself one of the primary elements of language. Descartes, you'll remember, began by saying, "I think, therefore I am." The operative word is "therefore." Before he believed that, he believed in the connectability of words, in the cogency of "therefores," in the fact that an inference from a premise would not let him down. Doctrines like the ontological proof of the existence of God really reduce to the same formula: I think, therefore God exists. God is really an inference, then, from the power of therefores. That is where the residual magic of the first phase is still operative, in the sense that words are ineluctably linked together. The most bizarre 
notions, like God predestinating people to damnation before they are born, may still be clung to because of the intensity of feeling. If you accept this, then you must, et cetera.

This phase is, as I say, an age of words as the expression of thoughts; and just as the kernel of the first phase is that of the god with a small $\mathrm{g}$, which is a metaphorical identity of a personality with an element in nature, so God with a capital $G$ is the central conception of this second phase. Instead of being metaphorical, it is rather what linguists call metonymic. In metonymy, you don't have the formula this is that, as you have in metaphor; you have this is put for that. Among other things, this includes the form, called technically the synecdoche, where the part is put for the whole. The word God with a capital $G$ is a metonymy because a name is finite and what it expresses is infinite, and it is therefore a part of a whole. In this phase of language we are in an age of commentary and, because of continuous prose, of rationalization. In continuous prose, the general principle is that when you are confronted with an inconsistency in something that you have to treat with respect, if you just keep on writing enough sentences, any statement whatever can be reconciled with any other. So you begin to get the encyclopedic thought systems of the Middle Ages and the Renaissance down to the age of Kant, which extend themselves and swallow everything like pythons swallowing sheep.

Occasionally you become aware of the tensions between the different phases of language. In St. Thomas's Summa Contra Gentiles, for example, there is a chapter with the title that "God Hates Nothing." Well, that's fair enough; a perfect being obviously couldn't hate anybody or anything, so St. Thomas has little difficulty proving that God hates nothing. Then he is confronted by a long list of things in the Bible that God is said to hate. Because he has to take the Bible seriously, he has to take the first phase of language seriously, so he chalks that up to his old friend analogy, analogy being essentially the conception developed in St. Thomas to harmonize his use of language with that of the Bible.

This phase of language is the language of the post-Biblical Christianity, which is largely Aristotelian in structure; and it's been characterized as late as the nineteenth century by Cardinal Newman when he said that the Bible was not there to teach doctrine but to prove it. What was taught, that is, was taught in continuous prose in a doctrinal structure and is then related by analogy to the metaphorical constructs in the Bible. Just as the first phase is hieroglyphic in an extended sense, so this phase is hieratic in the sense of being, as we should say now, elitist: it is taught by an educated minority to the rest of the human race.

Every phase of language tends to expand into an encyclopedic system, though the word "system" strictly applies only to this particular phase of language, for a reason which has been very well expressed by Wallace Stevens in one of his finest poems, "Description Without Place." There he says that man does not live directly in nature; he lives within his own constructed world in which nature is included. A parallel of latitude divides most of Canada from most of the United States. The birds and the 
buffaloes and the seeds and the trees don't pay any attention to this parallel of latitude, but, on the other hand, the world of birds and buffaloes and seeds and trees doesn't exist for us either except as part of a human construct which includes parallels of latitude. This is peculiarly, I think, the attitude of what I've called the hieratic or second phase of language. At least it's then that it becomes most obvious.

The Bible seems to me fundamentally a product of a metaphorical conception of language. This first phase is closest to its successor, the second phase, in the genre that we call oratory, because oratory is a highly figured form of speech. It is hieratic in the sense that it tries to draw its audience into a closer unit, but it makes use of the same rhetorical and figurative devices that metaphor does. The bulk of the Bible is really different forms of oratory, or what is sometimes called kerigma or proclamation; and there are many phases in it like "he that hath ears to hear let him hear" which suggest, again, the drawing of an audience into a tighter unit of belief and assent.

The third phase of language begins in English literature with Bacon, theoretically, and more effectively with Locke, this being a period in which the conception of language is fundamentally descriptive; that is, language is thought of as reflecting the facts of time and space in the outer world. Consequently its controlling figure is neither the metaphor nor the metonymy but a kind of suppressed simile-this is like that-this being a structure of words and that being whatever the structure of words describes. This third phase is the conception of language that completes the cycle from the first. In the first or metaphorical phase of language, the word evokes the image; in this phase the image evokes the word, and the word is the servo-mechanism of the things that the words are there to interpret. This conception of language depends on truth, in the sense of the truth of correspondence. A verbal structure is set up to describe something in the world outside it, and it is considered true if it is a satisfactory verbal replica of what it describes. This phase also uses continuous prose, like the preceding phase; the subject is still pursuing the object through a forest of predicates. But it is 2 non-figurative kind of writing. The descriptive writer tends to avoid what he would consider merely verbal devices, tries to define things clearly and consistently, tries to collect facts that can be verified by others, and sets out his arguments in full. Ideally, such writing has the virtues of clarity and honesty and appeal to a demotic or democratic consensus. Elsewhere I have suggested that it is this conception of language, along with the principle of public access to its documents, that makes democracy a working possibility.

If I am right, we have gone around a cycle of language in three phases, and if Vico is right, we go into a ricorso then and start the cycle all over. Well, I don't like cycles; I think the cycle is simply a failed spiral. I think that when we come to the end of a cycle we ought to move up to another level and proceed accordingly. Consequently I find it an extremely reassuring aspect of the contemporary scene that there should be so intense an interest in the resources and capabilities of language itself. Language has become a model for a study which has drawn together a great variety of humanistic and social scientific disciplines: linguistics, literary criticism, phenomenology, socio- 
linguistics, anthoropology, and a number of others. It seems to me historically right that there should be this interest in the possible resources of language because obviously society would be at its most efficient if all varieties of language were recognized to have their own validity, their own place, and their own context in the linguistic scene. At the same time, I have a particular interest in this early phase of language out of which the Bible grew because the Bible is a logo-centric document, that being one of the things which makes it so intensely relevant to our contemporary concerns. It is the book that presents the word as the fundamental image for the relation of God to man and for the destiny of mankind generally. It is interesting that its most sacred sentence, from many points of view, is the sentence, "In the beginning was the word," and that there have been interesting attempts to translate that in both the second and third phases of language. In the Renaissance, Erasmus translated it as in principio erat sermo. That is, in the beginning was not the word but the interconnection of ideas or thoughts out of which words grow and of which they are the expression. That is a typical second-phase attitude to the first. Then in Goethe's Faust we have the character Faust, who claims to have studied theology but obviously doesn't understand much of it, attempting to struggle with the same verse from John. He finally winds up with Im anfang war die tat, the "act," of which the word is merely the record. As soon as he says that, of course, he is fair game for Mephistopheles, who turns up and takes him over. And it serves him right.

Now it seems to me that it is the fundamental function of literature, and more particularly of poetry, to keep recreating in society that first phase of language, that original, metaphorical sense of immediacy, a sense of identity between personality and nature. That is why there have been so many arguments like Peacock's "Four Ages of Poetry" which demonstrate that the poet is a hopeless anachronism, or rather an atavism, that he has fallen behind in the race of civilization, and that he belongs to essentially a crude and archaic form of society. That is quite true; it is what percipient critics have always said. Elizabethan critics, for example, kept uniting the poet's function with the most ancient periods of society which they associated with legendary names like Hermes Trismegistus, and Orpheus; and when Shelley said that poets were the "unacknowledged legislators" of the world, he was really calling on the same conception.

Literature of course comes to terms with other conceptions of language. During the second phase it came to terms with it largely through allegory, in which the images and metaphors of poetry ran along in a continuous counterpoint against the conceptions and doctrines which had a higher authority than the images of the poet, as we can see very clearly in Dante. In the third phase, literature produces what is called realism, sometimes an almost documentary realism, where the words reflect events in social conditions and, again, attempt to tell the 'honest truth' about what is going on in the world outside. All through literature there is, as one of its central principles, and perhaps its organizing principle, the principle of recreation. Every poet recreates previous literature in his own way and in his own form. And just as art recreates 
previous art, so criticism recreates art in a different conceptual framework. The Elizabethan critics adopted the maxim ut pictura poesis, poetry is a speaking picture. By that they meant that something in the past is brought into the present and given the immediate, almost hallucinatory clarity of something in the present.

That brings us to a fourth figure of speech. I've spoken of metaphor where this is that, of the metonymy where this is put for that, and the simile where this is like that; but those are all figures in space. There seems to be no figure that is related directly to time, not at least in that group. In time we have a figuration in which this anticipates that and, in reverse, that recalls this. That is the kind of figure which obviously has to be connected with any conception of recreation in time. And that fourth figure, which we call typology, is the figure dominating the Bible, where everything that happens in the Old Testament, in the Christian view, is an anticipation of what happens in the New Testament. What happens in the New Testament, moreover, recalls what is done or prophesied or seen in the Old. But of course the Old Testament keeps recreating itself, as we can see if we compare the books of Chronicles, for example, with the books of Kings. It is partly this sense of figuration in time that gives to the Biblical religions, both Judaism and Christianity as well as, to some extent, Islam, an historical dimension, which, as it is a commonplace to observe, is different from that of other forms of mythology.

The conception of recreation, of course, can go further. Plato even went to the point of saying that all knowledge was, in effect, a re-cognition, a knowledge of something already known. He tends to refer that to a kind of rudimentary reincarnation doctrine that what you know you actually remember from a previous existence. Whether that's true or not, it certainly is true that what you know is what other people have known, and it is a recognition for us in that sense. Even in the ordinary sense of the term, recreation, whatever is valuable or positive in it, has to do with re-creation in a more specific sense. If you go out to play a game of golf or tennis, you are recreating your athletic skill; and if you go to a movie, you are recreating your knowledge of movies. It is that element which gives value to one's leisure activities. Certain elements of criticism which have preoccupied Harold Bloom, the conception, for example, of the "anxiety of influence" and the fact that every poet misreads and misunderstands his predecessors, and has to if he is to speak with his own voice, depend again on this matter of recreation. The archetype of all that is in the Bible, at least in the Christian Bible, where the New Testament's conception of the Old is, from the point of view of Judaism, a preposterous and perverse misunderstanding.

This conception of language, as I say, tends to extend encyclopedically because of the Wallace Stevens principle that we live not directly in the world but in our own construct of the world, or as I should say, because I am not a poet, we live within a mythological universe. That of course brings up the question of the word "myth" and what it means. To me a myth means fundamentally what it means in Greek, mythos, meaning a narrative or a sequential arrangement of words. I think that anything which can be read sequentially, that is any book except possibly a telephone book, does have 
a narrative and therefore a mythos. In the first phase of language, these mythoi, or narrative sequences, are for the most part stories. They move through a concrete world of personalities and metaphors. In the second phase of language they become arguments or conceptions, but the important thing is that story myths and argumentative or conceptual myths have a very strong family likeness and are related by analogy. That is in my opinion a still unexplored issue in criticism, one that I think will bear a good deal of examination.

Myth in this sense, of course, has no connotation whatever of the untrue or the imaginary. If we look at Gibbon's Decline and Fall of the Roman Empire, we can see that that was intended to be a work of historical scholarship. But if we look at the phrase "decline and fall," we can see what Gibbon's mythos was, the principle on which he selected his material and arranged his words in a linear sequence. That myth has to be there whether the content is true or imaginary.

According to Artistotle, the historical narrative is particular and the poetic narrative is universal. Therefore the historical narrative is judged by whether it is true or false and the poetic narrative is not. But I think that imposes an oversimplified duality on the situation. In teaching the Bible, I am often faced with a resentful student saying to me, "But you're saying that the story of the Gospels is just a myth, and therefore that Jesus had no historical existence." It's a more intricate matter than one would think to get all the fallacies in that statement unsnarled. To me the statement that the Gospel is a myth and the statement that the Gospel tells a story are exactly the same statement, and it's clear that the relationship between poetry and history is a midway one. It doesn't fall exactly into either camp. The writers of the Gospels obviously assumed the historical existence of Jesus; they would never have written a line if they hadn't. At the same time they were not writing biographies. They were concerned with the life of Christ as a universal event, falling in between the poetic and the historical. That in between area can only be the area of what I've called typology, the area where this anticipates that and that recalls this. Those writers selected for their account of Christ that which fulfills the Old Testament prophecies, and they were concerned with nothing else. Whether they were right or not, the distinction has proved very fortunate in our own cultural heritage. It means that the Biblical religions have a diachronic mythology, to use that term, which moves in time and has an historical dimension, whereas the pagan mythologies are synchronic: they deal with elements in nature that recur cyclically but are the same thing every time. This historical element in the Bible is also a personal element. Jesus and Adonis are both dying gods; they have very similar imagery and very similar rituals attached to them; but Jesus is a person and Adonis is not.

This conception of recreation means that there are two major directions in criticism. There is a progressive, forward movement in criticism which is a continuous accretion of commentary which keeps wrapping up the original text in thicker and thicker wrappings. We can see that in the history of Biblical interpretation, where the centuries of commentary form a long tradition of their own. Then with the rise of 
the descriptive phase of language, we begin to get also a critical activity that moves backwards towards the genesis or origin of whatever it is engaged in studying. In the case of Biblical criticism, we have not only the advancing movement of commentary as it adapts the Bible to later phases of society and culture, we also have an archaeological and historical criticism that moves backwards from the Bible itself into the original rituals, into the earliest possible phallic or other symbolisms and mythologies out of which the Bible grew. There comes a point, of course, where the only thing we can reach that is sufficiently primitive to go on with is the investigator's own subconscious, and at that point scholarship has to turn psychological. If, for example, we take the familiar lines of the hymn,

His chariots of wrath the deep thunderclouds form

And dark is his path on the wings of the storm.

we should say that if we were to take that literally (whatever literally means) we should be faced with about as crude and superstitious a notion as it was possible to put into words. But of course we don't take it that way; we take it as poetic metaphor. Like other hymns, its language is founded on the Bible, for the Psalms tell us that God or Jehovah rode upon the wings of a cherub and did fly. But in the Bible it is still poetic metaphor. I doubt if you can go back to any society sufficiently bemused or bewildered actually to believe that when they heard thunder in the sky it was God riding around in some kind of private aeroplane. But what we do come back to is a point at which such a conception was the only way of expressing, in language, what was actually a quite authentic experience. And so the whole problem resolves itself into a linquistic problem rather than a purely historical or archaeological one.

The general moral of all this, I think, is that a myth - which may be a story in one phase and an argument in another, or keeps on being a story in literature-a myth means everything that it has in fact been made to mean. For St. John of the Cross, the sixteenth century Spanish mystic, the Song of Songs becomes an allegory of the soul as the bride and of Christ as the bridegroom. We can't say that that is a wrenching or distorting of the Song of Songs; it's an integral part of its development in culture. On the other hand an historical critic would trace the Song of Songs back to the wedding festivals and their rituals, to the erotic love songs out of which it grew; and again we can't say that that is something which the Song of Songs has left behind. It makes no attempt to leave it behind; it incorporates it with the greatest enthusiasm.

There is a continuous process, then, moving forwards and backwards, which literature expresses and which criticism takes account of. In revolving around as I have been all this evening the theme of humanism in society, I am isolating specifically what seems to me at the moment the central issue of humanism, which is the issue of language and the way that society uses language. This is an issue which, as I have said, nearly all of the humanities and many of the social sciences have converged on in our day. But it seems to me that it is literature and the study of literature which stands in the center of all this activity and which is, to use a phrase of Blake, holding the end of a golden string. 